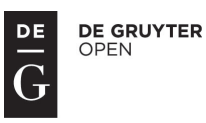

\title{
Social RiSk MaNagement aS A STRATEgY IN THE Fight Against Poverty and Social Exclusion
}

\author{
Hana Vykopalová ${ }^{1}$
}

\begin{abstract}
Questions surrounding the fight against poverty and social exclusion have become a global priority. Poverty and its causes are perceived as differences in the economic and social development of each individual continent and country. Social risk management was developed by the World Bank as a specific conceptual framework of social protection strategy and includes prevention, mitigation and the management of social risks. The diverging causes of poverty across the European continent assume a different approach in identifying causes and social risk management. An important aspect of the EU's social policy is to combat unemployment and social exclusion with the support of the European fund to help the extreme poor and other EU funds, e.g. EQUAL. The appropriate implementation of social risk management in each country is a prerequisite for reducing extreme poverty. Social risk management as a global strategy to combat poverty and extreme poverty is a challenge in the field of education which offers a new range of views and is generating more complex professional competencies in education and new possibilities for university graduates in the labor market.
\end{abstract}

\section{Keywords}

Social Exclusion, Poverty, Sources of Social Risks, Strategies to Combat Poverty, Social Risk Management

\section{Introduction}

The fight against poverty and social exclusion is an issue with which humanity around the world has been fighting for hundreds of years. Poverty and its causes are different on different continents, and there must also therefore be different strategies for solving them. The sharp rise in poverty accompanied by social exclusion in the world population has become an impulse for its solution. The most powerful economic and political powers, such as the

${ }^{1}$ Faculty of Safety Engineering, VŠB - Technical University of Ostrava, Czech Republic. E-mail: vykopalovah@seznam.cz. 
World Bank, the UN and the EU, have set strategies systematically aimed at reducing extreme poverty. But the implementation of these measures meets with a number of barriers at the national level, which pushes back the deadlines for faster poverty reduction. Social risk management systems implemented based on the specifics of each country are promising options to address the most pressing issues of poverty and social exclusion. The aim of this article is to highlight this global social problem and suggest some possible solutions.

\section{Social exclusion as a multidimensional problem}

Issues of social exclusion and poverty are becoming key issues on a global scale. Social exclusion can be understood as a number of social mechanisms leading to threats to the integrity and cohesion of the collectivity and challenges to the common identity of their members. (Mareš, Sirovátka, 2008).

Various forms of social exclusion, including spatial exclusion, can be seen in different societies throughout their social development.

Social exclusion is a comprehensive concept, with a number of different aspects. Economic exclusion is largely perceived as long-term unemployment, low income and income poverty, while social exclusion represents a breakdown of the traditional home, isolation, homelessness, crime, and other manifestations of social pathology. An aspect of political exclusion is the denial of political rights, and the inability or failure to participate in political life. The community aspect of exclusion is represented by a devastated environment, lack of services and support networks; individual exclusion can be seen through physical or mental disability or illness, lack of education and skills, loss of self-confidence and self-esteem. Group exclusion is seen as the concentration of these characteristics leading to the exclusion of certain social groups. The spatial aspect of social exclusion is especially important in terms of social policy, where the concentration of socially-excluded individuals and social groups in a limited space brings with it higher social risks in the form of crime, high unemployment, low-quality dwellings, poor transport access, etc., which in turn increases the risk of escalating the social exclusion of these social groups. (Percy-Smith, 2000).

Social exclusion, as the social exclusion of marginal groups, can be seen as a handicap or lack in certain areas, but in some cases this can be understood as earmarking, targeted, deliberate or privileged, with the purpose of respecting traditions and lifestyle. In this case, social exclusion need not be understood as a handicap, but as intentional. Global issues dealing with the consequences and causes of social exclusion and poverty, however, relate to involuntary social exclusion, where they are most frequently cited as the reason for a lack of education, low skills, unemployment, material deprivation, etc., which are the main causes of misery and poverty. 


\section{Poverty and social exclusion}

Poverty is traditionally seen as a state where a lack of money does not ensure important (basic) necessities at a reasonable level. The socioeconomic development of modern society, while accepting this assessment, also gives it another quantitative dimension. This mainly distributes poverty as absolute or relative and deals with the social consequences of poverty. (Tomeš, 1996)

Measurement of the poverty line is based on the state of the population; it is an indicator of economic and social development and at the same time a signal for emergency social assistance (welfare benefits for the poor).

Nearly half the world's population now lives below the poverty line, although there are profound differences in the level of wealth between countries and individuals. The main causes of poverty in some countries and their inhabitants are seen in the conditions and pace of economic growth, which were shaped by historical global social development. Social development and the technical maturity of some countries and continents, especially Europe and the US, contributed to the rapid development of modern economies with sustained economic growth, based on technical progress and the development of production processes, resulting in a consistently rising GDP. A number of developing countries and regions, especially Africa, disadvantaged in terms of historical and social development, are still some of the poorest places in the world. The causes of poverty in the sub-Saharan African continent are therefore of a somewhat different nature from poverty and its causes in the now developed countries of Europe and the US. Out of this concept arises differences in how to resolve issues of poverty and extreme poverty.

According to data from the World Bank, 21 percent of the world's population lives in extreme poverty (people living on a dollar and a quarter a day, lack of material needs and health care) According to the World Bank, extreme poverty could cease to exist in the world in nearly two decades, if the international community were to commit to this goal and support economic growth in developing countries.

\section{The conceptual framework of the World Bank in the fight against poverty}

In the fight against poverty and extreme poverty, the World Bank in 1990 created a specific conceptual framework for social risk management (SRM). It expanded the traditional framework of social protection to include strategies for the prevention, mitigation and management of basic living needs and to support the motivation to work. SRM focuses on the poor and extremely poor who are most vulnerable to social risks and is aimed at managing the worst situations of crises and economic shocks. SRM strategies seek to reduce the vulnerability of the poor and encourage them to participate in decision-making, alongside motivating them to engage in work that would get them out of chronic poverty. The following events are the most significant, according to intensity, on the scale used to identify sources of social risks (Holzmann, Jorgensen, 1999): 
- Catastrophic vs. non-catastrophic events. At the beginning of the scale are events that occur with low frequency but which have serious consequences on household incomes, e.g. bereavement, accident or illness, persistent unemployment, technical ineptitude. The other end of the scale contains events with high frequencies of occurrence that do not have such a dramatic impact. These include temporary illness, crop failure, temporary unemployment. Protection against these noncatastrophic events can be found in mechanisms such as loans with zero interest, etc.

- Idiosyncratic (micro) shocks vs. covariance (macro) shocks, leading to losses either only in some households in the community, such as a lack of communication, short illness or frictional unemployment, or hitting all households at the same time, such as drought, inflation or financial crisis.

- Individual vs. repetitive, consecutive shocks, e.g. drought occurring as a single event and the associated loss or consecutive shocks, i.e. drought and subsequent disease, death, etc. Repeated shocks bring more risks, are difficult to handle and require reliable access and resources.

\section{Strategic bases in the management and prevention of poverty and extreme poverty}

The reduction strategy for extreme poverty, poverty prevention strategies and coping strategies of poverty and extreme poverty are based on the underlying causes of poverty, on geographic, economic and social changes over the last two centuries (Bloom, Sachs, 1998), such as:

- Extreme weather conditions

- Lack of fiscal policy

- Low level of education, lack of competitiveness and lack of innovative approaches

- Geopolitics and contractual relations relating to the export of raw materials

- Demographic population increases associated with an increase in the basic necessities of life that families are unable to provide

- Government failure to build infrastructure and social protection

In cooperation with selected governments of some African countries, feasibility studies of social risk management were carried out.

The different causes of poverty on the European continent and the US requires a different approach to identifying those causes and in social risk management. An important aspect of the EU's social policy is the fight against unemployment, which in 2013 reached among people under the age of 24 the threshold of $28 \%$, while there are EU countries where youth unemployment is a serious social problem and structural boundaries unemployment in this age group exceeds $35 \%$. In this context, the European Commission has set five scenarios and strategies for combating unemployment, with an emphasis on the coordination of unemployment benefits and harmonization of legislation on cross-border labor migration. 
Key issues in the fight against unemployment and poverty, according to the European Commission (2015) are:

- building a partnership approach, especially in the field of labor and employment opportunities

- building up an efficient information strategy aimed at young people, including functioning personal advice, recommendations for individual action plans, including individually-tailored support systems

- building support measures for labor market integration, the creation of conditions and opportunities to return to the process of education, promotion of entrepreneurship and self-employment, a reduction in non-wage labor costs, state aid and targeted subsidies for salaries and recruiting workforce, promoting job mobility

- using Union funds: full and optimized use of financial instruments of cohesion policy, for example, the European Fund to help the extreme poor

The high increase in the number of people suffering from severe material deprivation triggered the release of Regulation (EU) No 223/2014 of the European Parliament and of the Council of 11 March 2014 on the Fund for European Aid to the Most Deprived; this urges Member States to become involved and take appropriate measures to prevent the deepening of material deprivation for some people. The Fund should strengthen social cohesion and contribute to reducing poverty in the EU. The EP regulation is another tool aimed at supporting national systems and providing material aid to the poorest, reducing material deprivation and contributing to the social inclusion of the extreme poor. The purpose of the Fund is to alleviate extreme forms of poverty, with the impact on social exclusion being greatest, such as homelessness, child poverty, food poverty, and to create an effective system to assist in integrating those affected into society. The budget of the Fund for 2014-2020 amounts to more than \$3.8 billion. Member States will also have to contribute a further 15 percent in domestic pairing financing (see the Regulation (EU) No 223/2014 of the European Parliament and of the Council of 11 March 2014 on the Fund for European Aid to the Most Deprived).

Another example of support from EU funds includes the activities of the EQUAL Community Initiative, which is one of four Community initiatives co-financed by the Structural Funds and corresponding to the EU social policy and its program. The aim of the initiative is to develop and implement tools to support the members of disadvantaged groups (long-term unemployed, low-skilled, graduates, senior citizens, people with disabilities, ethnic minorities, women, refugees, etc.), who face discrimination or unequal treatment either in employment or when engaging in job searches. One of the thematic areas of EQUAL is focused only on issues of social inclusion and employment for asylum seekers. Critical key principles support the implementation of EQUAL, namely, thematic approach, international cooperation, partnership, joint decision-making, innovation and gender mainstreaming, i.e. taking into account the principle of equal opportunities for women and men in all planned and implemented activities and supported projects (MLSA, 2006). 


\section{Proposals for implementation}

In the interest of the efficient and effective implementation of the actions financed by the Fund, EU Member States should work together to improve the system of analysis and social risk management.

The area of social policy is very large and broad. Individual EU countries have their own regulations and opinions in this area and therefore recommendations by the EP and the Commission only constitute a framework. The manner in which EU legislation is implemented depends on the conditions of the country's space management for social risk management. This results in a whole range of approaches and knowledge of legislation, fiscal policy, economics, political science, law and social work, so that they effectively fulfil the recommendations and regulations of the EU, in accordance with the tools and conditions prevailing in the country, but also in cooperation with other EU member states. A current example is the issue of the social protection of migrant workers, which envisages coordinated multinational cooperation, especially on the legislative and socio-legal level, among a number of EU countries.

The future direction of European social policy was outlined by the European Commission in July 2008 with the adoption of the so-called renewed social agenda, which aims to modernize the EU's social policy to fit the needs of the twenty-first century. One of the principles is the free movement of workers within the EU, with a legal basis in Directive no. 492/2011 on the free movement of workers within the European Union; Regulation (EC) no. 883/2004 on the coordination of social security systems and its implementing of Regulation (EC) no. 987/2009. The basic principle is to ensure that every EU citizen has the freedom to operate their profession in any Member State, including the coordination of social security (European Parliament, 2016).

Management of social risk management necessarily seems the work of officials of state institutions, in terms of dealing with the paperwork associated with the implementation of EU legislation into national policies, as well as several non-profit organizations focused on social work and social assistance. At this level are developed activities in the field of education and training programs aimed at raising educational levels and achieving an optimal labor market as a strategy to fight against poverty.

\section{Conclusion}

The global issue of the fight against exclusion and poverty has various causes, consisting mainly of socio-historical developments that require different approaches and strategies for addressing the global challenge and finding effective strategies for social risk management. This is a challenge in the field of education, which offers a new range of views and in generating more complex professional competencies in education and new possibilities for university educated people and their labor market.

The article presents a summary of the facts, alerts and commentary on the global problem of social exclusion and poverty, including the possibility of some solutions. 


\section{References}

Bloom, D. E., Sachs, J. D. (1998). Geography, demography and economic growth in Africa. Harvard Institute for International Development.

European Commission. (2015). Employment, Social Affairs \& Inclusion: Youth employment [online]. Retrieved January 7, 2015, from http://ec.europa.eu/social/main.jsp?cat$\mathrm{Id}=1036 \&$ langId=en.

European Parliament. (2016). Free movement of workers [online]. Retrieved March 1, 2016, from http://www.europarl.europa.eu/atyourservice/en/displayFtu.html?ftuId=FTU_3.1.3. html.

Holzmann, R., Jorgensen, S. (1999). Social protection as social risk management: conceptual underpinnings for the social protection sector strategy paper. Journal of International Development, 11(7), 1005-1027.

Mareš, P., Sirovátka, T. (2008). Sociální vyloučení (exkluze) a sociální začleňování (inkluze) - koncepty, diskurz, agenda. Sociologicky časopis/Czech Sociological Review, 44(2), 272.

Ministry of Labour and Social Affairs (MLSA). (2006). Welcome to EQUAL [online]. Retrieved January 7, 2015, from http://www.equalcr.cz/clanek.php?lg=2\&id=373.

Percy-Smith, J. (2000). Policy Responses to Social Exclusion. Towards Inclusion? Buckingham: Open University Press.

Tomeš, I. (1996). O chudobě jako o sociální události. In: Sociální politika, teorie a mezinárodní zkušenost. Praha: Socioklub, 1996, 126-130. 